027.1 Поповић, J. С.

\title{
Тринаест књига из личне библиотеке Јована Стерије Поповића
}

\author{
Драгана Ракић \\ Градска библиотека Вршац \\ draganarakic10@gmail.com
}

\begin{abstract}
Сажетак:
Јован Стерија Поповић (1806-1856), један од најзначајнијих писаца српске књижевности, просветитељ и научник, поседовао је богату личну библиотеку од које је данас, нажалост, сачувано само 13 књига. Идентификоване су као Стеријине на основу његовог аутографа који се налази на њима или на основу стихова које је својом руком записао. Свих 13 се чувају у Вршцу, 10 припадају Градској библиотеци, а три су у власништву Градског музеја. Претпоставља се да се понека књига са Стеријиним потписом може данас наћи код приватних колекционара.

Након Стеријине смрти, његову библиотеку је наследила супруга Јелена. Она је већину књига продала Францу Ветлу, књижару и издавачу из Темишвара, тако да је лична библиотека чувеног писца веома брзо након његове смрти расформирана.
\end{abstract}

Кључне речи: Јован Стерија Поповић, лична библиотека, Градска библиотека Вршац, Градски музеј Вршац, културно наслеђе, књиге

\section{Јован Стерија Поповић, писац, просветитељ, научник}

Јован Стерија Поповић свој печат није оставио само у књижевности и позоришној уметности, већ и у области просвете, законодавства, лексикографије, науке. Био је међу оснивачима и утемељивачима основних институција културе ондашње Србије, која је 1804. године, након Првог српског устанка, започела свој пут ка модернизацији. Рођен у Вршцу 13. јануара 1806. године, ${ }^{1}$ од оца Стерије Поповића и мајке Јулијане рођ. Нешковић, ћерке познатог српског сликара Николе Нешковића, овај професор латинског, адвокат, министар просвете, законодавац, просветитељ, научник и књижевник, био је један од најученијих Срба свога доба.

Након завршетка студија права у Кежмарку (Словачка) враћа се 1830. у Вршац, где почиње да ради као професор латинског језика у приватној школи и тај посао обавља до 1836. године. Потом се бавио адвокатуром, да би крајем 1840. конкурисао и био примљен на место професора природног права у новооснованом Лицеју у Крагујевцу. Године 1842. постављен је за начелника у Попечитељству просвештенија и на тој функцији остаје до 1848, када даје оставку и враћа се у Вршац. Још док је био у Крагујевцу покреће иницијативу са Атанасијем Николи-

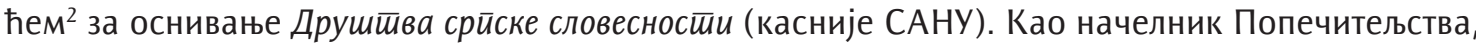
указом оснива Народни музеј 10. маја 1844. године као Музеум сербски, који је на једном месту требало да „сабере старине и да их за потомство сачува“. ${ }^{3}$ Пише први просветни закон обновљене Србије, уџбенике латинског и немачког језика, реторике, математике и географије. Данас се о њему говори као о класику српске књижевности и „оцу српске драме“. Умро је у Вршцу 26. фебруара 1856. у педесетој години живота.

\footnotetext{
Датуми су наведени по новом календару, по старом, Стерија је рођен 1. јануара 1806, а умро је 26. фебруара 1856.

2 Атанасије Николић (1803-1882) инжењер, професор математике и први ректор Лицеја у Крагујевцу, један од оснивача Друштва српске словесности. Заједно са Јованом Стеријом Поповићем основао је прво професионално позориште код Срба „Театар на Ђумруку“ у јесен 1841. године.

${ }^{3}$ Градски музеј Вршац, Историјат музеја, преузето 19. 7. 2018, http://www.narodnimuzej.rs/o-muzeju/istorijat-muzeja/.
} 
Човек широке ерудиције и интересовања, према писању његових савременика, а затим и наследника и изучавалаца, имао је богату личну библиотеку. ${ }^{4}$ Прве записе о томе налазимо код њега самог, јер како пише у Зайискама: „Чело мога кревета стоје књиге на рафу. Када би се какво земљотресеније догодило, могле би ме књиге убити, и тако би се могло казати да сам од књига умро."

Збирка књига коју је поседовао Јован Стерија Поповић, судећи према његовим интересовањима, а посебно цитатима које је наводио у свом књижевном опусу, свакако је морала бити брижљиво одабрана. ${ }^{6}$

Нажалост, данас за свега 13 књига можемо са сигурношћу тврдити да су биле део велике личне Стеријине библиотеке. Идентификоване су као његове на основу аутографа који се налази на њима или на основу стихова који су записани његовом руком. Свих 13 књига се налазе у Вршцу (10 су у власништву Градске библиотеке, а 3 припадају Градском музеју).

Основно је питање шта се заправо десило са овом библиотеком, од које је данас сачувано толико мало наслова.

На основу сећања и казивања књижевника Миодрага М. Пешића, дугогодишњег библиотекара Народне библиотеке у Београду, у депоу изгореле библиотеке налазили су се низови књига са забелешкама да су припадале Стерији, али када је 1953. године Милан Токин покушао да истражи ове наводе ништа детаљније није успео да сазна. ${ }^{7}$

Поставља се питање да ли је Стерија, напуштајући Београд 1848. године, тамо оставио своје књиге. Тешко је поверовати у овакву могућност, поготово ако се зна да се у Вршац повукао баш са жељом да се у миру бави писањем.

Миливој Јовановић ${ }^{8}$ и стериолог Милан Токин ${ }^{9}$ сматрају да је главни „кривац“ за немаран однос према Стеријиној личној библиотеци супруга Јелена, њен законски наследник. Јовановић и Токин тврде да је распарчавање ове библиотеке почело још за време Јелениног живота, у периоду између 1856. и 1877. године. Обојица сведоче да им је Феликс Милекер ${ }^{10}$ рекао да је Франц Ветл, књижар и издавач из Темишвара, одмах након Стеријине смрти, откупио од његове удовице већи део књига и однео их у Темишвар. Том приликом је и сам Феликс Милекер набавио неколико публикација које су припадале чувеном писцу и ставио их у неинвентарисани депо Градске библиотеке, где су пронађене тек после ослобођења, 1944. године.

\section{Тринаест књига из личне библиотеке Јована Стерије Поповића}

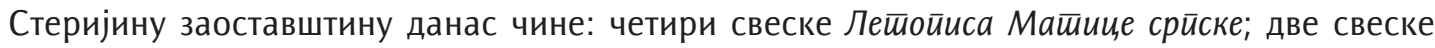
Песама Кристофа Мартина Виланда; три у кожу повезана броја Виландовог часописа Немачки Меркур, један комплет годишта Политиички разіовори йокојника (1792) издавача Мориса Фла-

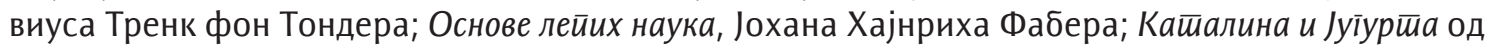

\footnotetext{
${ }^{4}$ Миливој Јовановић, „Нешто о личној библиотеци Јована Стерије Поповића“, Библиошекар бр. 1 (1950): $406-407$.

${ }^{5}$ Јован Стерија Поповић, Дела (Београд: Драганић; Суботица: Минерва, 2004), 637.

${ }^{6}$ Неки аутори које Стерија цитира или спомиње су: Хомер, Хорације, Вергилије, Овидије, Теренције, Федрус, Плутарх, Демокрит, Платон, Аристотел, Сервантес, Шекспир, Ариосто, Молијер, Самјуел Батлер старији (тзв. Хјудибрес-Батлер), Милтон, Лоренс Стерн, Данијел Дефо, Бифон, Лесинг, Лихтнберг, Клопшток, Ласаж, Клаурен, Гете, Шилер, Вилхелм Шлегел, Хердер, Виланд, Вајсе, Морис Флавиус Тренк фон Тондер, Волтер, Лопе де Вега, Готшел, Ломоносов, Флориан, Виктор Иго, Коцебу, Жан Пол, Чоке, Блумауер, Менцл, Бајрон, Берне... Од домаћих писаца: Доситеј, Рајић, Мразовић, Мушицки, Видаковић, Вујић, Караџић, Хаџић, Везилић.

${ }^{7}$ Милан Токин, „Књигољубац Стерија“, Књижничар св. 17-18 (1956): 444.

${ }_{8}^{8}$ Миливој Јовановић (Рудна (Румунија) 1886 - Вршац 1968), библиотекар Градске библиотеке у Вршцу од 1934. Постао је први управник ове библиотеке после Другог светског рата. Написао је велики број текстова са темама из вршачке историје и објавио их у завичајној периодици, у зборницима Матице српске и стручним библиотечким часописима.

${ }^{9}$ Милан Токин (Вршац, 1909 - Нови Сад, 1962), дипломирани правник, новинар, библиотекар, стериолог. Писао је песме, новеле, књижевноисторијске студије, чланке и расправе. Објавио је монографију Јован Сйерија Пойовић (Београд 1956) и приредио је сабрана дела Јована Стерије Поповића (Нови Сад 1958)

${ }^{10}$ Феликс Милекер (Вршац, 1858-1942) оснивач Градске библиотеке и Градског музеја у Вршцу и њихов доживотни управник.
} 
Гаја Салустија Криспа и Нсйорија славенских језика и књижевносиии Павела Јосефа Шафарика који се чувају у Градској библиотеци и Градском музеју у Вршцу.

Основана је претпоставка да се понека књига са Стеријиним аутографом може наћи код приватних колекционара.

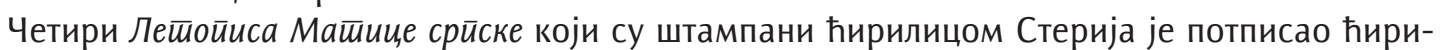
личним словима (Јоанна С. Поповића), а остале књиге које су штампане немачком готицом потписивао је латиницом (Joannis S. Popovits). Потписивао се тамнобраон мастилом, слова су му лепа, дугуљаста, читка и укошена надесно.

У Градској библиотеци у Вршцу налази се следећих 10 књига:

1. Сербске лешиойиси за їog. 1826: перва частица (година II, част 4), штампан у Будиму 1826. Стеријин потпис налази се на насловном листу испод амблема Матице српске. Ћирилични потпис гласи: Јоанна С. Пойовића. У овој свесци на стр. 80-85 објављена је Стеријина Поема славеносербскому нароgу на ново леше 1826. У првом стиху треће строфе руком је поправио штампарску грешку коју су превиђали и каснији редактори издања његових дела. Тако да овај стих треба да гласи: „Хелкиона обитателнице!“ (а не „обитателиште“ како се и данас штампа).

2. Сербске лешеойиси за їog. 1827: друга частица (година III, частица 9), штампан у Будиму 1827. На насловном листу, испод амблема Матице српске налази се Стеријин потпис, ћириличним словима: Јоанна С. Пойовића gар Машиице Србске. На непагинираним странама ове свеске Леш̄ойиса, а испред списка претплатника је Објавленије - позив на претплату на Стери-

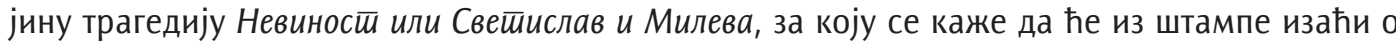
будућем пештанском вашару на Светог Јована. Може се сазнати и да је ова књига требало да има илустрације рађене у бакрорезу и да ће у претплати коштати 24 крајцаре у сребру.

3. Сербске леш̄ойиси за їog. 1828: друга частица (година IV, частица 13), штампан у Будиму 1828. На полеђини насловног листа налази се Стеријин аутограф исписан ћириличним словима: Јоанна С. Пойовића gар оg Майице.

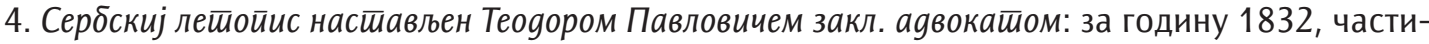
ца трећа (година VIII, частица 30), штампан у Будиму 1832. На унутрашњој страни предње корице налази се Стеријин потпис ћирилицом: Јоанна С. Пойовића gap og ì. Пахомиа. Реч је о Пахомију Јовановићу, Стеријином пријатељу из Вршца, калуђеру и професору Богословије, коме је испевао Ogy (1834), а који је касније постао архимандрит сремског манастира Шишатовац. На стр. 65-76 је посмртно слово које је Пахомије Јовановић одржао над гробом Синесија Радивојевића, адиминистратора вршачке епархије који је умро 18. априла 1832. у Вршцу. На страни 73. Стерија је руком исправио штампарску грешку, тако што је једном хоризонталном линијом прецртао реченицу која је два пута заредом поновљена („да нисмо већ уверени“).

5. Песме (Poetische Schrifte)од Кристофа Мартина Виланда. Ова прва свеска има 352 стране, штампана је у Цириху 1770. Књига је прекоричена, има светлосиво-плаве картонске корице. На унутрашњој страни предњих корица некада је стајало име ранијег власника и датум када је она набављена, али је преко тога касније прелепљен екслибрис Градске књижнице Вршац. Међутим, Милан Токин је књигу имао у рукама пре него што је екслибрис залепљен, тако да је прочитао име претходног власника - то је био Мардел фон Данијел, католички свештеник у Вршцу (од 1822. до 1863) и човек за кога се сумњало да је 1849. убио вођу побуњених Срба Александра Кумановића. ${ }^{11}$ Фон Данијел је ову књигу набавио 1803. и то је својом руком забележио на унутрашњој страни предњих корица. Стеријин потпис је на насловном листу, исписан је латиницом и гласи: Joannis S. Popovits. На два места у књизи је Стеријино подвлачење.

\footnotetext{
11 Токин, Нав. дело, 447.
} 
6. Песме (Poetische Schrifte)од Кристофа Мартина Виланда. Ово је друга свеска која је такође штампана у Цириху, 1770. Књига је прекоричена, има исте светлосиво-плаве корице као и прва свеска и 288 страна. Стеријин скраћени латинични потпис се налази на насловном листу испод вињете и гласи JSPopovits. У овој свесци су многобројна Стеријина подвлачења.

7. Књижевни часопис Немачки Меркур (Der teutsche Merkur) за месеце јануар-март 1773. Часопис је штампан у Франкфурту и Лајпцигу 1773, а издавао га је Кристоф Мартин Виланд. Има 288 страна, повезан је у тамнобраон кожни повез са златотиском на хрпту. На полеђини прелиминарне странице је Стеријин потпис латиницом ((Joannis S. Popovits).

8. Друга свеска Виландовог часописа Немачки Меркур (Der teutsche Merkur) за месеце јануар-март 1774. И она је повезана у тамнобраон кожни повез, али нема Стеријин потпис, међутим има стихове исписане његовом руком. Наиме, на последњем празном листу графитном оловком исписао је пет стихова. Реч је о концепту за песму „Надгробије владики Стефану Поповићу“. ${ }^{2}$

9. Трећа свеска Виландовог часописа Немаики Меркур (Der teutsche Merkur) за месеце април-јун 1774, такође нема Стеријин потпис, међутим на последњем празном листу има два стиха записана његовом руком графитном оловком. И она је, попут претходне две, повезана у исти кожни повез са златотиском на хрпту. Садржи врло велики број подвлачења Стеријином руком.

10. Часопис Политиики разіовори ӣокојника (Politische Gespräche der Todten) за 1792. годину је заправо подлистак Neuwieder zeitunga који је издавао Морис Флавиус Тренк фон Тондер. Књига је прекоричена, данас има картонске корице светлобраон боје. Стерија се потписао латиницом (Joannis S. Popovits) на почетку текста на трећој страници. Ово дело Стерија помиње у свом Роману без романа. На последњој страни форзаца забележено је име ранијег власника књиге - Constantin Spaits (Константин Спајић).

Поред описаних 10 књига које су власништво Градске библиотеке, још три се данас чувају у Градском музеју у Вршцу. Све имају Стеријин потпис:

1. Основе лейих наука (Anfangsgründe der Schönen Wissenschaften), аутора Јохана Хајнриха Фебера је публикација штампана у Мајнцу, 1767. Стеријин потпис латиницом је на насловном листу испод вињете (Joannis S. Popovits). Књига је у кожном повезу, са лепо украшеним хрптом са златоутиснутим оранаментима.

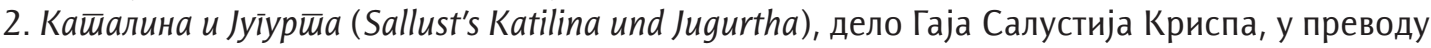
Јохана Карла Хека, штампано је у Бечу 1800. године. Има 250 страна. Ова књига служила је Стерији као приручник приликом наставе латинског језика у Вршцу, а касније и при

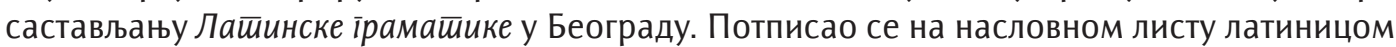
(Joannis. S. Popovits), а одмах поред потписа, са десне стране, налази се печат панчевачке трошарине (овални печат са аустроугарским двоглавим орлом са натписом при дну: K 30 gst-Amt. Pancsow). Овај печат отвара питање да ли се некада (бар у области Војне границе) плаћала градска трошарина на књиге које су уношене.

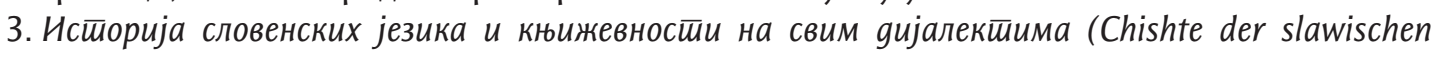
Sprache und Literatur nach allen Mundarten) од Павела Јосефа Шафарика, штампана је у Офтену, 1826. Књига је у полукожном повезу, има 524 стране. Стеријин потпис је на насловном листу латиницом, а испод њега, црквенословенским верзалним словима, утиснуто је име ранијег власника: Антоније Арнот. ${ }^{13}$ На другом предњем форзацу натпис Ex

\footnotetext{
12 Владика Поповић је био Стеријин пријатељ који је страдао 1849. године.

${ }^{13}$ Антоније Арновљев Арнот (1808-1841), професор физике на Лицеју у Београду и уредник Србске новине или Маїазина за хуgожесйво, књижесйво и моgу. Умро у Београду 11. септембра 1841. године.
} 
libris Antonii Arnoth, Advocati, а лево од тога број 34088. Нешто ниже је Стеријиним рукописом записана забелешка: пољски szsc. szkrz = шт, шкр. На овој књизи се могу пратити сви њени власници и пут којим је доспела до Градског музеја у Вршцу. Стерија је књигу, после смрти Антонија Арнота откупио од његове удовице. После Стеријине смрти, књига је доспела у власништво његовог брата Ђорђа С. Поповића, затим у руке његовог зета Светислава Цвејића, па његовог сина Лазара Цвејића, да би је Градском музеју у Вршцу поклонио др Мираш Кићовић, који ју је 1924. купио у Вршцу од књижара Милана ПеткаПавловића. Подвлачења и бележења на маргинама су многобројна.

\section{Закључна разматрања}

Брзој и лакој распродаји Стеријиних књига, осим његове удовице Јелене, која није имала свест о важности очувања ове збирке, свакако је допринела и чињеница да у том тренутку у Вршцу није радила ниједна читаоница или библиотека која би евентуално била заинтересована да откупи и сачува у целини Стеријину библиотеку. Иако је Вршац међу првим градовима у Војводини имао своју српску читаоницу, која се још 1837. под именом Касино у Вршиу јавља као пренумерант за Маїазин за хуgожесшево, књижесшево и моgу, ${ }^{14}$ а коју касније у свом писму упућеном Људевиту Гају спомиње и вршачки адвокат Григорије Милутиновић, ${ }^{15}$ она нажалост, престаје са радом пре Стеријине смрти у време Буне народа у Војводини (1848/49).

Рестаурација и конзервација свих десет књига које су у власништву Градске библиотеке Вршац урађене су током 2016. у лабораторији Библиотеке Матице српске и оне се данас чувају у специјалним орманима на Одељењу старе и ретке књиге вршачке Библиотеке. У наредном периоду, на исти начин би требало заштитити и преостале три књиге које припадају Градском музеју, јер су у веома лошем стању. У плану је да свих 13 књига буду унете у електронски $P e-$

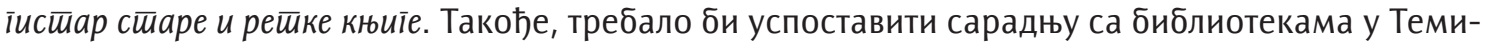
швару и покушати утврдити да ли нека од тамошњих библиотека поседује књиге из Стеријине заоставштине. На тај начин би се проширио овај скромни списак некада богате личне библиотеке Јована Стерије Поповића.

\section{Литература и извори:}

1. Gradski muzej Vršac. Istorijat muzeja. Preuzeto 19. 7. 2018. http://www.narodnimuzej.rs/o-muzeju/ istorijat-muzeja/.

2. Jovanović, Milivoj. „Nešto o ličnoj biblioteci Jovana Sterije Popovića“. Bibliotekar br. 1 (1950): 406-407.

3. Popović, Jovan Sterija. Dela. Beograd: Draganić; Subotica: Minerva, 2004.

4. Tokin, Milan. „Knjigoljubac Sterija“. Knjižničar sv. 17-18 (1956): 442-450.

\footnotetext{
14 Лист Србска новина или маїазин за художесшиво, књижесииво и моgу, који је уређивао Антоније Арнот, објављиван је 1838-1839, два пута недељно. У Пешти је излазио 1838, а у Будиму 1839. године. Од 1839. променио је наслов у Маїазин за хуgожесииво, књижесивво и моgу. Овај забавни књижевни лист, богато илустрован, доносио је и библиографске податке о српским књигама и новинама, литерарне прилоге и практичне поуке, а пропраћен је и списком пренумераната. То је први српски лист који обавештава о моди.

15 У писму које је вршачки адвокат Григорије Милутиновић 20. октобра 1840. упутио Људевиту Гају записано је да су Вршчани једва дочекали време „главног Сабора Касине наше“ како би се претплатили на Нлирске новине и Данииу. Ово писмо под сигнатуром R4702 чува се у Националној и свеучилишној књижници у Загребу.
} 


\title{
Thirteen Books from the Personal Library of Jovan Sterija Popović
}

\begin{abstract}
Summary
Jovan Sterija Popović (1806-1856), a classical writer of Serbian literature, an educator and a scientist, had a rich personal library that, unfortunately, has not been preserved as a whole. Only 13 books from this library have been saved. They are identified as Sterija's property based on his autograph, or the verses Sterija wrote on them with his hand. All 13 books are kept in Vršac, 10 books belong to the City Library, and 3 books are owned by the City Museum. It is assumed that some books with Sterija's signature could be found in private collections as well. After Sterija's death (1856), the writer's wife Jelena inherited his personal library. She sold most of the books to Franco Vettel, a bookshop owner and publisher from Timișoara, so Sterija's personal library was dispersed quickly after his death. Sterija's legacy consists of four volumes of the chronicles of Matica Srpska (Letopis Matice srpske), two volumes of Christoph Martin Wieland's poems (Poetische Schrifte), three issues of Wieland's magazine The German Mercury (Der teutsche Merkur) bound in leather cover, one annual set of issues of Political Talks of the Dead (Politische Gespräche der todten, fd J. 1792), Basics of Good Science (Anfangsgründe der Schönen Wissenschaften) by Johann Heinfich Faber, Catalina and Jugurta (Sallust's Katilina und Jugurtha) by Gaius Salustius Krisp and History of Slavic Languages and Literature (Chishte der slawischen Sprache und Literatur nach allen Mundarten) by Pavel Josef Šafař́k.

Keywords: Jovan Sterija Popović, personal library, City Library of Vršac, Vršac City Museum, cultural heritage, books
\end{abstract}

Примљено: 22. јула 2018. Исправке рукописа: 6. септембра 2018. Прихваћено за објављивање: 15. септембра 2018. 

Creative Commons Attribution-NonCommercial-NoDerivatives 4.0 I nternational License. 